\title{
Selecting location for a new business unit in ICT industry*
}

\author{
Sanja Marinković ${ }^{1}$, Ilija Nikolić ${ }^{2}$, Jovana Rakićevic ${ }^{3}$
}

\begin{abstract}
Location theory is studying the impact of location on any economic activity, trying to understand where operations should be settled and what should be the reason for such a decision. The aim of this paper is to discuss and prioritize the key location determinants for successful selection of an optimal location for a business unit in the ICT industry. It emphasizes the importance of this concept in ICT sector today when the digitalization and big internet revolution occurs. The initial determinants were formed based on the literature review and evaluated through two rounds of the Delphi study among experts from ICT companies in Serbia. The second goal of the study was to reach a consensus about the relative importance of the agreed determinants. According to the obtained results using the AHP decisionmaking model, the priority in selecting a location for a business unit in the ICT industry is human resource availability, second is the political and economic environment, and the third is the competition. The paper finds that political and economic strategies start to play an important role in ICT market, as governments are getting more interested in this industry. The study confirmed that due to a shortage of labour supply and fierce competition in the ICT sector, the concept of location selection is an important success factor for sustainable growth and development of ICT organizations.
\end{abstract}

Key words: location selection, location determinants, Delphi study, AHP decisionmaking, ICT industry

JEL classification: D70, L21, M15, M21, R39

\footnotetext{
* Received: 02-05-2018; accepted: 27-11-2018

1 Associate Professor, University of Belgrade, Faculty of organizational sciences, Jove Ilica 154, 11000 Belgrade, Serbia. Scientific affiliation: technology management, innovation management, operations management. Phone: +381698893176. E-mail: marinkovic.sanja@fon.bg.ac.rs.

2 Master student, University of Belgrade, Faculty of organizational sciences, Jove Ilica 154, 11000 Belgrade, Serbia. Scientific affiliation: ICT management, international management. E-mail: ilija89.n@gmail.com.

3 Teaching Assistant, University of Belgrade, Faculty of organizational sciences, Jove Ilica 154, 11000 Belgrade, Serbia. Scientific affiliation: technology management, technology entrepreneurship. Phone: +381698893562.E-mail: jovana.rakicevic@fon.bg.ac.rs.
} 


\section{Introduction}

Location theory that studies how geographic location impacts any economic activity, tries to provide an answer to where should economic activity settle and what is the reasoning behind such a decision (Drezner and Hamacher, 2001).In predicting long-term survival and growth, the location of a company, warehouse, hotel or a plant has always played a vital role(Aras et al., 2004; Yong, 2006; Chou et al., 2008a; Özcan et al., 2011).The field of location selection has attracted significant interest of both academia and practice, which is reflected in an extensive literature presenting different methodologies for facility location selection (see e.g. Yang and Lee, 1997; Tzeng et al., 2002; Chu, 2002; Chou et al., 2008b; Kahraman et al., 2003; Govindan et al., 2016).The importance of evaluating and selecting a location for a new hotel, bank or a plant wasalways evident for many reasons, but the challenge of choosing location in information and communication technology (ICT) industry was recognized recently as a critical success factor for sustainable growth and development (Van Oort et al., 2003; Narula and Santangelo, 2009; Duvivier et al., 2018).

Modern business cannot be imagined without the ICT. Staying competitive in today's terms means that services should be available to customers in a few clicks, and companies need to be capable of processing huge amount of data in real time for accurate decision making. Also, it implies having backend systems that can effectively manage the production, inventory or other areas of business. In the era of the internet and the changing nature of business communication, the issue of the location of ICT companies and business units is becoming particularly interesting. The first thought might be that location in this field is becoming less important, having in mind unlimited possibilities of communication. However, location selection has its specificity, considering the intangible nature of information as a resource, value chain specifics in this industry, and changed needs for modern knowledge-workers. Today it is interesting to discuss if the location has still equal importance in the ICT industry as before the big "www" revolution. The paper aims to review, select and prioritize the critical determinants for successful selection of an optimal location for a business unit operating in ICT industry, and at the same time to emphasize the importance of this concept in ICT sector. Therefore, in this paper, we set the following two hypotheses. (H1): It is possible to determine the relevant set of factors for location selection of a business unit operating in the ICT industry. (H2): It is possible to prioritize the relevant set of factors for location selection of a business unit operating in the ICT industry.

The paper is organized as follows. Section 2 reviews the relevant literature for the problem of business location selection. Particular emphasis is on specific characteristics of business units operating in the ICT industry. Section 3 presents the research methodology - the research framework, methods, and the rationale behind choosing the set of determinants for location selection in the ICT industry. 
Section 4 explains the sample, questionnaire, and the primary results of the first phase of the research used for creating the relevant set of factors for optimal location selection examined in the second phase. Section 5 presents and discusses the results. Section 6 concludes the paper and gives the limitations, as well as future research directions.

\section{Literature review}

The ICT industry is one of the key instruments for the development of an economy (Muñiz and Cuervo, 2014). As a consequence of such growth, the competition on this market became fierce. The rapid growth in total employment of specialists in this area confirms the increasing importance of ICT in the global economy (European Commission, 2017). Providing the services of best quality while keeping the costs in control is the formula for success. As an appealing solution for the management of ICT companies, the outsourcing strategy is often chosen. In this setup, companies retain only their most experienced engineers and managers, while all the other responsibilities are given away to the supplier, usually coming from a less developed country where costs are typically lower than in the home country of the company.

However, with this trend, another challenge emerged where the demand for highly capable software engineers is now larger than the general supply on the markets. Hence, for outsourcing companies to grow, they have to choose an optimal location, where the long-term success and stability is possible. Company location can be defined as a geographical and central place for the company to realize all its basic occupations and to carry on relations with its close and far environs (Burdurlu and Ejder, 2003). Location choice is a strategic decision which influences revenue and costs also, and the main question for starting a business is where to locate a facility, particularly in this age of global markets and global production (Gušavac et al., 2014). The location theory of business locations applies explicitly to the choice of the location to establish a business (Van Noort and Rejimer, 1999). The development of theories in this field recognized the following: 1. (Neo) Classical location theories: Land use, Industrial Location (Weber and Isard), Central Places (Christaller and Lösch), Spatial Competition (Hotelling); 2. Behavioural location theory; 3. Institutional Approach, 4. Agglomeration Theory (ala Michael Porter Cluster Theory). In general, within economic geography, neo-classical, behavioural, and institutional location theories are used to explain firms' migration (Pen, 1999).

ICT industry serves as an intermediary between customers and multinational corporations enabling a company to establish an online presence and global reach. Efficient ICT systems are important to minimize the number of manuals, administrative tasks that service personal need to perform (Kowalkowski et 
al., 2011). Because of its advantageous capabilities to dramatically accelerate communication speed and increase information channels, ICT saves costs while increasing the output and quality of most service productions (Chen and Wang, 2010). Since the ICT is becoming ever-so-important in the service industry, it is common that every such company has an ICT department of their own. To further cut the costs, companies are also turning to outsourcing as a business strategy. IT outsourcing, defined as the process of commissioning part or all of an organization's IT assets, people, and/or activities to one or more external service providers, has emerged as a viable option in information systems management (Lee, 2006). There is still an ongoing debate in the business management world whether outsourcing is a successful strategy, and if it is applicable for any business case. Primary motivators for such strategies are also changing. Furthermore, as the motivations of outsourcing are increasingly evolving from cost reduction to business performance improvement, it is crucial for organizations to align their outsourcing strategy with their business strategy (Lee, 2006). However, "many business organizations often treat outsourcing as de facto solution, based on assumption, that savings will be achieved without in-depth analysis of the real strategic and economic factors and values" (Boguslauskas and Kvedaravičienè, 2008). Even today outsourcing as a strategy is a debatable topic among business professionals. It is also mentioned in the journal article as "very topical issue" (Andone and Pavaloaia, 2010: 164). While it can be very successful, outsourcing can prove to be a very difficult challenge to achieve. Majority of reasons may be connected with the way a company decided to opt for a strategy of outsourcing.

To identify factors or criteria for location choice it should start from product or service characteristics and business sector (Stojanović, 2005). In this paper, the primary interest is on the ICT industry. This industry, depending on a segment, can be categorized as the production as well as a service industry. Further, within the production segment, ICT companies may be involved in the production of for endusers (e.g. personal computers) or their core business may include the production of certain high technology parts (e.g. computer processors). On the service end of the spectrum, ICT companies may further differentiate based on for whom they provide the services, end customers or to intermediates. In the case of outsourcing companies, as analysed in the previous section, services are not being offered directly to the customers. Rather, the company which is outsourcer is providing the value for end-customers. Based on this differentiation, factors for location selection in the ICT context may differ. In the table below, general factors for business location selection are presented. 
Table 1: Summary of major factors and sub-factors affecting international location decision

\begin{tabular}{|c|c|}
\hline Major factors & Sub-factors \\
\hline Costs & $\begin{array}{l}\text { Fixed costs; transportation costs; wage rates and trends in wages; } \\
\text { energy costs; other manufacturing costs; land cost; construction/ } \\
\text { leasing costs and other factors (e.g. R\&D costs, transaction and } \\
\text { management costs etc.) }\end{array}$ \\
\hline $\begin{array}{l}\text { Labour } \\
\text { characteristics }\end{array}$ & $\begin{array}{l}\text { Quality of labour force; availability of labour force; unemployment } \\
\text { rate; labour unions; attitudes towards work and labour turnover; } \\
\text { motivation of workers and workforce management }\end{array}$ \\
\hline Infrastructure & $\begin{array}{l}\text { Existence of modes of transportation (airports, railroads, roads and } \\
\text { sea ports); quality and reliability of modes of transportation; quality } \\
\text { and reliability of utilities (e.g., water supply, waste treatment, power } \\
\text { supply, etc.) and telecommunication systems }\end{array}$ \\
\hline $\begin{array}{l}\text { Proximity to } \\
\text { suppliers }\end{array}$ & $\begin{array}{l}\text { Quality of suppliers; alternative suppliers; competition for suppliers; } \\
\text { nature of supply process (reliability of the system) and speed and } \\
\text { responsiveness of suppliers }\end{array}$ \\
\hline $\begin{array}{l}\text { Proximity to } \\
\text { markets/customers }\end{array}$ & $\begin{array}{l}\text { Proximity to demand; size of market that can be served/potential } \\
\text { customer expenditure; responsiveness and delivery time to markets; } \\
\text { population trends and nature and variance of demand }\end{array}$ \\
\hline $\begin{array}{l}\text { Proximity to parent } \\
\text { company's facilities }\end{array}$ & Close to parent company \\
\hline $\begin{array}{l}\text { Proximity to } \\
\text { competition }\end{array}$ & Location of competitors \\
\hline Quality of life & $\begin{array}{l}\text { Quality of environment; community attitudes towards business } \\
\text { and industry; climate, schools, churches, hospitals, recreational } \\
\text { opportunities (for staff and children); education system; crime rate } \\
\text { and standard of living }\end{array}$ \\
\hline $\begin{array}{l}\text { Legal and regulatory } \\
\text { framework }\end{array}$ & $\begin{array}{l}\text { Compensation laws; insurance laws; environmental regulations; } \\
\text { industrial relations laws; legal system; bureaucratic red tape; } \\
\text { requirements for setting up local corporations; regulations } \\
\text { concerning joint ventures and mergers and regulations on transfer of } \\
\text { earnings out of country rate }\end{array}$ \\
\hline Economic factors & $\begin{array}{l}\text { Tax structure and tax incentives; financial incentives; customs } \\
\text { duties; tariffs; inflation; strength of currency against US dollar; } \\
\text { business climate; country's debt; interest rates/exchange controls } \\
\text { and GDP/GNP growth, income per capita }\end{array}$ \\
\hline $\begin{array}{l}\text { Government and } \\
\text { political factors }\end{array}$ & $\begin{array}{l}\text { Record of government stability; government structure; consistency of } \\
\text { government policy; and attitude of government to inward investment }\end{array}$ \\
\hline $\begin{array}{l}\text { Social and cultural } \\
\text { factors }\end{array}$ & $\begin{array}{l}\text { Different norms and customs; culture; language and customer } \\
\text { characteristics }\end{array}$ \\
\hline $\begin{array}{l}\text { Characteristics of a } \\
\text { specific location }\end{array}$ & $\begin{array}{l}\text { Availability of space for future expansion; attitude of local } \\
\text { community to a location; physical conditions (e.g., weather, close to } \\
\text { other businesses, parking, appearance, accessibility by customers, } \\
\text { etc.); proximity to raw materials/resources; quality of raw materials/ } \\
\text { resources and location of suppliers }\end{array}$ \\
\hline
\end{tabular}

Source: adapted from (Gušavac et al., 2014) 


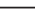
Zb. rad. Ekon. fak. Rij. $\cdot 2018 \cdot$ vol. $36 \cdot$ no. $2 \cdot 801-825$

Given one of the main reasons for opting for outsourcing strategy and that is cost reduction, costs as a location factor may play a critical role. ICT is a knowledgeintensive industry, where the success of a company usually relies on how capable the workforce is. Therefore, labour characteristics should play a significant part in the decision. Infrastructure factors may also play an important part since ICT companies (especially the outsourcing ones) depend on reliable infrastructure when it comes to transportation and telecommunication systems. Similarly, it can be seen that for outsourcing company most of the factors and sub-factors are relevant.

\section{Research methodology}

The research was conducted in two phases. These phases are connected with two hypotheses set in this paper. Figure 1 presents the research framework which specifies the steps followed in conducting this research.

Figure 1: Two-phase research framework
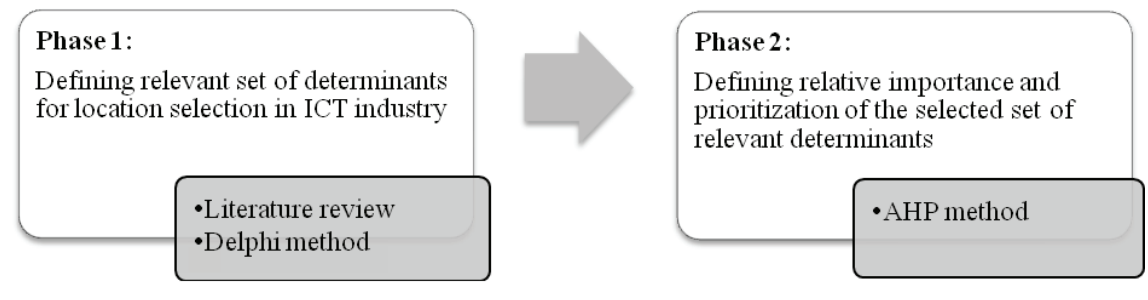

Source: Authors' framework

Introducing the problem of location selection for a business unit in the ICT industry firstly implies the understanding of contributing determinants of such decision. In the first phase of the research, the primary determinants were formed based on the literature review. Then, the Delphi study was conducted among experts from ICT companies in Serbia to define the final set of the determinants. The study was designed to offer initial determinants for the defined problem leaving the option to the experts to extend the initial list or to agree to the same. The following ten factors for choosing an optimal location for opening a new business unit in the ICT industry were defined and presented to the experts. These factors were grouped in three principal groups: quantitative, qualitative, and other - ICT specific. Figure 2 presents ten determinants grouped into three categories. The goal of the first phase was to reach consensus on the relevant determinants among those by using the Delphi method.

The second phase of the study was to reach consensus about relative importance between the determinants agreed in the first phase. Once the structure of the problem has been designed, the prioritization of each element started to determine 
the relative importance of each criterion, and each alternative according to each criterion. Prioritization procedure implies the pairwise comparison of elements at the same level of the hierarchy and regarding the elements of the upper level of the hierarchy. The examined group of experts does the pairwise comparison of criteria relevance and fills the matrix with numbers on the Saaty's nine-point scale (Saaty, 2008). The same procedure is repeated for comparisons of alternatives relevance from the perspective of each criterion. Once all elements at both levels (Level 1 represents criteria, and Level 2 represents sub-criteria) were compared by the experts, according to the AHP procedure, the matrices are constructed. Afterwards, aggregation of the results and calculation of the final scores for each criterion, and alternatives for each criterion was performed. Finally, the prioritization of the alternatives was performed based on the aggregated scores which indicate the relevance of each determinant for optimal location selection in the ICT industry.

Figure 2: Framework for defining location selection determinants in the ICT industry

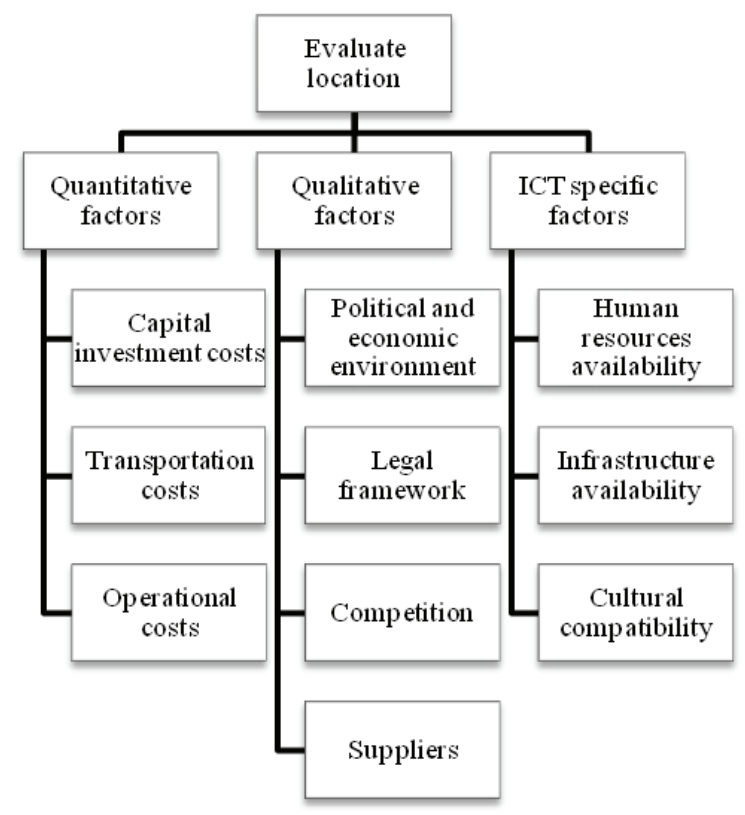

Source: Authors' framework diagram

Thus, in this study, two methods were used to collect quantitative data: the Delphi (first phase) and the Analytic Hierarchy Process - AHP (second phase). 


\subsection{Methods: Delphi and Analytic Hierarchy Process}

Delphi method, developed by the RAND Corporation in the 1950s, represents a systematic procedure that collates the opinions of a diverse group of experts located in different geographical areas whose opinions are important for decision analyses. The idea is to obtain the most reliable consensus of a group of experts (Dalkey and Helmer, 1963). Through the Delphi technique, different responses and views are obtained for the underlying problem resulting in generating new ideas and unique suggestions (Eskandariet al., 2007).It is an iterative process. In each round, experts are asked to fill in questionnaires individually and anonymously. After each round, all responses are summarized by the moderators and reported back to the panelists, who then have an opportunity to revise their answers in the next round. The process continues until a set level of stability in responses is reached (Linstone and Turoff, 2002; Novakowski and Wellar, 2008). The goal of each round is to reduce the range of experts' responses and obtain the expert consensus. Since its first introduction, researchers have developed variations of the method. Okoli and Pawlowski (2004) highlight one variant that has received widespread use, and that is the "ranking-type" Delphi which is used in this study. Okoli and Pawlowski (2004) also provide detailed guidelines for the process of selecting appropriate experts for the Delphi study.

Another method used in this study is the AHP. It is a well-known and most widely applied in solving decision-making problems (Mousavi et al., 2013). Thomas L. Saaty $(1977,1980,1990,2013)$ developed this method as an analytical tool, which is based on a pairwise comparison of the hierarchy elements. Therefore, it implies decomposition of a problem into a hierarchy. To decompose a problem, a researcher needs to consult previous experiences and attempts for a particular topic of interest. The criteria and sub-criteria are not equally important to the decision on each level of the hierarchy, and each alternative's rate is not the same for each criterion. AHP can provide an analytical process that combines and consolidates the evaluations of the alternatives and criteria by either an individual or a group involved in the decision-making task. The further advantage of the method lies in its ability to recognize inconsistent judgements (Chen, 2006). Combined with the Delphi method it provides a framework for solving different types of multi-criterion decision problems based on the relative priorities assigned to each criterion's role in achieving the stated objective (Tornjanski et al., 2015).

\subsection{Rationale behind choosing the set of location determinants}

\section{(a) Quantitative factors}

Multinational corporations commonly capitalize on foreign business opportunities by engaging in foreign direct investment (FDI) which refers to investment in real assets (such as land, buildings, or even existing plants) in foreign countries (Madura and Fox, 2011). The costs generated as a direct result of FDIs are capital investment 
costs. In the ICT industry the trend of outsourcing is evident, and therefore this determinant should be analysed with foreign perspective emphasized. Though, the same costs are relevant when a company is investing locally. It is also important to understand that capital investment costs can be influenced by other factors like economic and political circumstances of a particular market. For example, costs may be lower due to the subventions programme that the government defines to encourage foreign investments into the local ICT sector. A different example would be progressive tax policy, where initial investment may look appealing to the investor, but after a more thorough evaluation it could turn out that projected benefits are not compensating real costs. Generally, an organization of economic activity in the geographic area depends crucially on the transportation of goods and people. Most consumption requires either the conveyance of finished goods or the transfer of people to the points at which goods and services are supplied (Redding and Turner, 2015). However, since ICT is primarily a service industry, the distance between delivery centres and customers may impact the costs. Further, the location of the company relative to the labour may also result in higher transportation costs on a regular basis to enable employees to deliver final products or services.

The conveyance of goods in the ICT sector has a different meaning, though, since the final product of the ICT industry is located in virtual space and can be transferred via the internet. A similar analogy could be made for raw materials and fuel since the only inputs ICT needs a part people is the electricity and the internet connection. These costs are influential but should be analysed as a part of operational costs. Increasing consumers' demand for lower-priced products is driving companies to find ways to have lower manufacturing costs. Companies have been forced to look for ways to control and reduce operational costs such as labour costs, inbound/outbound shipping costs, utility costs, corporate tax rates, occupancy costs, and other factors - most of which were also listed as top-ten factors in the Area Development Corporate survey (Comerford and Spano, 2017).

A similar trend is widely present in the ICT industry, where labour costs are the most significant part of operational costs. To reduce their costs, ICT companies from the US or Western Europe are relocating their development centres towards countries with cheaper labour force. The demand is significantly higher than the supply on the ICT labour market. Therefore, employees from ICT companies are used to extra benefits not usually found among companies from other sectors such as flexible working hours, working from home policies, benefits packages etc. Since there are not enough ICT professionals available on the labour market, companies are putting a high effort to attain and retain talents. This is also a determinant in operational costs which could impact the decision for choosing an optimal location. Another significant operational cost for an ICT company is related to the infrastructure and software required for development. However, compared to the labour costs, those are less significant (Matteucci et al., 2005). 


\section{(b) Qualitative factors}

When considering the political factors, a company needs to evaluate the influence a government has on the economy. Those factors may include tax policy, trade restrictions and tariffs, etc. On the other hand, a country's stability and risks (such as hostile takeovers, wars, sanctions, etc.) also need to be considered. Every country also has a strategy of growth. This strategy may involve the production of some products or services to be rejected, while others to be supported by subventions, government loans or other means. In general, measures of fiscal policies may also be considered as part of the political environment.

In the case of ICT industry, one can notice that economic factors are recognized by all countries of the world in various extents. These factors can influence greatly how the business operates in specific markets. This is especially the case for developing countries as supported by the analysis of the European Parliament: "The unequal provision of opportunities to access and contribute to information, knowledge and networks and to benefit from the development- enhancing capabilities of ICT is known as the Digital Divide. In the past ICT was generally considered a luxury and was not considered a viable option for development policy where other needs, such as building roads and hospitals and providing drinkable water, etc. were considered more urgent. However, the Digital Divide has today become one of the most prominent considerations in the Development Divide" (Pedrelli, 2001). Political and economic strategies are starting to play a bigger role in the ICT market, as governments are getting more interested in this industry.

While the legal framework is also impacted by the government and is consisted of several different elements, the political and economic factors are oriented to the government from the perspective of foreign trade policies and fiscal policies. Legal elements may include employment regulations, competitive regulations, health and safety regulations, product regulations, antitrust laws, patent infringements, etc. Respecting those regulations is even more complex in case of multinational corporations that are doing businesses in different countries, even different continents.

Competition has proved to be a critical force in operation of various organizations regardless of their industry of belongingness (Indiatsy et al., 2014: 74). Factors that are influencing the level of competitiveness can be extracted. Those may include, but not limited to, cost of production, the price of final products, marketing activities, customer loyalty, and access to technology. In Porter's Five Forces model (Porter, 1980; 1985; 2008), a special attention is given to the suppliers, referring to companies that supply raw materials, equipment, machinery, associated services and labour (Indiatsy et al., 2014). In Porter's model, the bargaining power of suppliers is seen as a force that may impact the competitiveness of a company. Suppliers can influence a company's price, quality, and overall delivery. Their roles are different in various industries. 


\section{(c) ICT specific factors}

ICT industry is an industry which is highly dependent on educated and experienced human resources. Shortage of software engineers is a problem in many countries. Therefore, human resources are becoming a bottleneck in meeting the market demand for software products. This refers to managing human resources in globally distributed teams, shortage of software professionals with sufficient knowledge and competencies, lack of well-developed HR systems and processes, high employee turnover, lack of work-life balance, and the problems associated with the use of contract employees (Agrawal et al., 2012). Regarding the EU, "in recent years, EU policies have given greater attention to ICT skills, and in particular to the employment of ICT specialists. The recently updated Digital Single Market strategy emphasizes the need for policies designed to boost stability in European labour markets and improve the EU's competitive position" (European Commission, 2017).

Infrastructure availability as a factor contributing to location-related decisions was analysed by Kadokawa (2011). He describes „,infrastructure-related reasons“, and names the reasons as "commuting convenience, industrial zoning, unrestricted environment, access to highway and business and logistic services" (Kadokawa, 2011). Infrastructure factors are industry-specific, and for the ICT sector, access to stable and high-speed internet connection, provided by internet service provider plays a critical role. The importance of world business has created a demand for managers sophisticated in global management and skilled at working with people from countries other than their own (Adler and Gundersen, 2008). ICT industry is mostly relying on virtual communication, teams, products, and services. Therefore, multicultural global teams are fairly common in the industry and a company has to do a cultural alignment among its business units. Therefore, when choosing the location for a new business unit, local management and working culture needs to be taken into an account.

\section{Empirical data and analysis}

In the first phase of the research, a two-round Delphi was conducted. The goal was to reach consensus among experts about the important determinants for optimal location selection for a business unit in the ICT industry. The initial determinants, grouped into three categories, were formed based on the presented literature review. The study was designed to offer these initial determinants for the defined problem. Afterwards, experts assessed the determinants with the idea to obtain the relevant set of criteria for the defined problem.

A web-based questionnaire was used for this ranking-type Delphi study. The consensus was considered met if $70 \%$ of experts agreed on each determinant. The same experts were involved in rounds 1 and 2 of the Delphi study. Experts were 
individuals being in management positions in the ICT companies. They were asked to rank the importance of determinants for an optimal location selection in the ICT industry. Their response reflects subjective attitude based on their knowledge and experience. A five-point Likert scale was used to evaluate the importance where: $1=$ unimportant; $2=$ slightly important; $3=$ important; $4=$ very important; $5=$ critical. Further, an open question was also given to the participants for comments or suggestions at the end of the questionnaire.

Fifteen ICT management experts from 6 IT companies operating in the service sector were asked to participate in this study. Ten of them took part in it, by providing answers based on their own experience and expertise in the ICT industry. This results in the participation rate of $66 \%$ in both rounds of the Delphi. Structure of the sample is presented in Table 2 .

Table 2: Sample structure

\begin{tabular}{|l|c|c|c|c|c|}
\hline $\begin{array}{c}\text { Management } \\
\text { level }\end{array}$ & \multicolumn{2}{|c|}{$\begin{array}{c}\text { No. and \% of experts per } \\
\text { managerial level }\end{array}$} & \multicolumn{2}{c|}{$\begin{array}{c}\text { Years of } \\
\text { experience }\end{array}$} & \multicolumn{2}{c|}{$\begin{array}{c}\text { No. and \% of experts per } \\
\text { years of experience }\end{array}$} \\
\hline First line & 6 & $60 \%$ & $0-3$ & 6 & $60 \%$ \\
\hline Middle & 2 & $20 \%$ & $3-6$ & 3 & $30 \%$ \\
\hline Top & 2 & $20 \%$ & $6-9$ & 1 & $10 \%$ \\
\hline Grand total & 10 & $100 \%$ & Grand total & 10 & $100 \%$ \\
\hline
\end{tabular}

Source: Authors' calculations

The average importance rating, standard deviation and percentage level of importance for each evaluated determinant after rounds 1 and 2, were obtained using statistical calculation. The most significant determinants (eight out of ten initially proposed), as recognized by the experts in the Delphi survey, are further evaluated through an AHP model.

In the second phase of the research, AHP is used to prioritize the relevant determinants of optimal location selection in the ICT industry, previously defined through the Delphi method. Figure 3 shows the research problem decomposed into a hierarchy structure that includes the overall goal, three criteria and eight subcriteria.

The highest level of the hierarchy is the overall goal, in this case, the optimal location selection of a business unit in the ICT industry. Below the overall goal, the next level represents the most significant criteria which influence this decision, including: quantitative context (F1), qualitative context (F2), ICT-specific context (F3). 
Figure 3: Structured AHP hierarchy for the defined problem

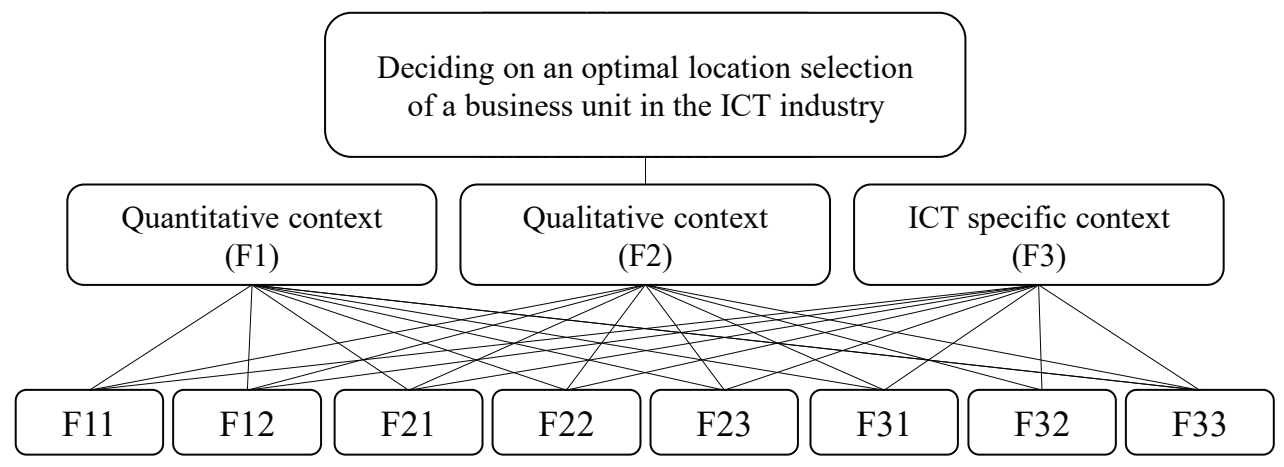

Source: Authors' diagram

As seen in the Figure 2, there is a total of 8 sub-criteria placed at the bottom level of the hierarchy. The factors related to quantitative context consists of two subcriteria: capital investment costs (F11) and operational costs (F12). Factors related to qualitative context are the following: political and economic environment (F21), legal framework (F22), and competition (F23).For the ICT-specific context, the following three sub-criteria are considered: human resource availability (F31), infrastructure availability (F32), and cultural compatibility (F33).

\section{Results and discussion}

\subsection{First phase - Delphi study results}

The significance of determinants as per Delphi results are presented in Table 3. In this study, $70 \%$ is set as the level of consensus among experts, and a level of $t_{n}=3$ is set as the acceptance level of determinant's importance. This means that all determinants that have average value above 3 are considered important to be further analysed and validated through an AHP model. According to the results, eight determinants are considered important, while two of them have the average value below 3 and are excluded from the analysis. Those are the transportation costs $\left(t_{n}=1.9\right)$ and the suppliers $\left(t_{n}=2.9\right)$.

According to the experts' opinion, the most significant determinant is the ICTspecific one, and that is the human resource availability. This is a general priority and a highly important issue in the ICT sector, both at the level of individual countries, and at the level of small ICT firms. In the quantitative context, the most important are the operational costs. It would be the most significant determinant to be considered when selecting a location. This is also by specific nature of ICT where 
capital investment and transportation costs are usually not high. In the qualitative context, political and economic environment and competition were recognized as more relevant. It could be concluded that in a very competitive industry such as ICT, specific political and economic conditions and regulations could be more or less stimulating in location decision making.

Table 3: Determinants and their significant after the second round of Delphi

\begin{tabular}{|l|l|c|}
\hline \multirow{2}{*}{$\begin{array}{c}\text { Quantitative } \\
\text { context }\end{array}$} & \multicolumn{1}{|c|}{$\begin{array}{c}\text { The significance of determinants } \\
\text { after II round of Delphi }\end{array}$} & $\begin{array}{c}\text { Average value } \\
\left(t_{n}\right)\end{array}$ \\
\hline \multirow{4}{*}{$\begin{array}{l}\text { Qualitative } \\
\text { context }\end{array}$} & Capital investment costs & 3.4 \\
\cline { 2 - 3 } & Operational costs & 4.3 \\
\cline { 2 - 3 } & Transportation costs & 1.9 \\
\cline { 2 - 3 } & Political and economic environment & 4.2 \\
\cline { 2 - 3 } $\begin{array}{l}\text { ICT-specific } \\
\text { context }\end{array}$ & Comal framework & 3.9 \\
\cline { 2 - 3 } & Suppliers & 4.1 \\
\cline { 2 - 3 } & Human resource availability & 2.9 \\
\cline { 2 - 3 } & Infrastructure availability & 4.7 \\
\cline { 2 - 3 } & Cultural compatibility & 3.2 \\
\hline
\end{tabular}

Source: Authors' calculation

In addition to the Delphi method, the reliability of the results obtained from the second round is estimated. The reliability result obtained using Cronbach's Alpha test shows the value of $0.665(\approx 0.7)$. According to De Vellis (2016), this result indicates the scale of reliable judgment. Therefore, experts' judgment on the importance of the determinants for optimal location selection is considered reliable and may further be evaluated through an AHP model.

\subsection{Second phase - AHP results}

When conducting an AHP analysis, there are three levels of evaluation: (a) evaluation of criteria regarding the overall goal, (b) evaluation of alternatives regarding each criterion, and (c) final evaluation of alternatives for achieving the main goal.

\section{(a) Results of level 1 - Evaluation of criteria}

Table 4 (part A) shows the results of a pairwise comparison of criteria against the overall goal. Based on the experts' opinion, ICT-specific context (F3) is important in comparison with quantitative context (F1) and equally important with qualitative context (F2). Qualitative context (F2) is important compared to quantitative context 
(F1). Table 4 (part B) illustrates the calculation of results that includes assigning the local weights according to the distributive way of calculation, following the AHP procedure, resulting in the prioritization of criteria at Level 1 for a successful decision on optimal location selection in the ICT industry. The outputs of this step are the weights of each criterion.

Table 4: Judgment comparison matrix of criteria in relation to the main goal (A) and vector of eigenvalues of comparison matrix and weight calculation (B)

\begin{tabular}{|c|c|c|c|c|c|c|c|c|c|c|}
\hline \multicolumn{5}{|c|}{ A - comparison matrix } & \multicolumn{6}{|c|}{$\mathrm{B}-$ vector of eigenvalues and weights } \\
\hline \multirow{2}{*}{\multicolumn{2}{|c|}{ Main goal }} & $\mathrm{F} 1$ & F2 & F3 & $\mathrm{F} 1$ & $\mathrm{~F} 2$ & F3 & \multirow{2}{*}{$\sum$} & \multirow{2}{*}{$\begin{array}{c}\text { Weights } \\
\left(\sum / 3\right)\end{array}$} & \multirow{2}{*}{$\begin{array}{l}\text { Priority } \\
\text { vector }\end{array}$} \\
\hline & & QUANT & QUAL & ICT-S & QUANT & QUAL & ICT-S & & & \\
\hline F1 & QUANT & 1.00 & 0.33 & 0.5 & 0.17 & 0.14 & 0.51 & 0.51 & 0.169 & $17 \%$ \\
\hline $\mathrm{F} 2$ & QUAL & 3.00 & 1.00 & 1.00 & 0.50 & 0.43 & 1.33 & 1.33 & 0.443 & $44 \%$ \\
\hline F3 & ICT-S & 2.00 & 1.00 & 1.00 & 0.33 & 0.43 & 1.16 & 1.16 & 0.388 & $39 \%$ \\
\hline & $\sum$ & 6.00 & 2.33 & 2.50 & & & & 3 & 1 & $100 \%$ \\
\hline
\end{tabular}

Note: QUANT - Quantitative context; QUAL - Qualitative context; ICT-S - ICT-specific context.

Source: Authors' calculation

Based on the results, the highest priority in the selection of an optimal business location in the ICT industry refers to the qualitative context $(\mathrm{w}=0.443)$, followed by the ICT-specific context $(\mathrm{w}=0.388)$. Quantitative context $(\mathrm{w}=0.169)$ has the least priority. Therefore, the priority of criteria at Level 1 relative to the main goal is as follows: F2 - F3 - F1. Consistency ratio was calculated to ensure the coherence of the judgments. Consistency ratio of the pairwise comparison matrix $\left(\lambda_{\max }\right)$ equals 0.017 , which is less than 0.10 . Therefore, according to Saaty (1986), the weights are shown to be consistent, and the comparison is acceptable.

\section{(b) Results of level 2 - Evaluation of alternatives}

Next steps show the analysis of evaluated alternatives at Level 2 towards the corresponding criteria placed at Level 1 in the AHP model. Table 6 shows the results of evaluated alternatives in relation to the quantitative context (F1). Since there are only two sub-criteria for F1, AHP analysis is not necessary for determining the weights of alternatives according to this criterion. However, for the purpose of demonstrating the methodology for finding alternatives' values according to one criterion, the AHP procedure is shown in Table 5. One could notice that the same procedure is used as for the analysis at level 1 .

Based on the results presented in Table 5, operational costs $(\mathrm{w}=0.751)$ have three times higher priority in selecting an optimal location, related to the quantitative 
context. Capital investment costs have the priority of $25 \%$. Consistency ratio of the pairwise comparison matrix is calculated as 0.067 , which is less than 0.10 . Therefore, the weights are shown to be consistent, and the comparison is acceptable.

Table 5: Comparison matrix of sub-criteria relative to the quantitative context (A) and vector of eigenvalues of comparison matrix and weight calculation (B)

\begin{tabular}{|c|c|c|c|c|c|c|c|c|}
\hline \multicolumn{4}{|c|}{ A - comparison matrix } & \multicolumn{5}{|c|}{$\mathrm{B}-$ vector of eigenvalues and weights } \\
\hline \multirow{2}{*}{\multicolumn{2}{|c|}{$\begin{array}{c}\text { F1 } \\
\text { Quantitative context }\end{array}$}} & F11 & F12 & F11 & F12 & \multirow{2}{*}{$\sum$} & \multirow{2}{*}{$\begin{array}{l}\text { Weights } \\
\left(\sum / 2\right)\end{array}$} & \multirow{2}{*}{$\begin{array}{l}\text { Priority } \\
\text { vector }\end{array}$} \\
\hline & & $\mathrm{CIC}$ & $\mathrm{OC}$ & $\mathrm{CIC}$ & $\mathrm{OC}$ & & & \\
\hline F11 & CIC & 1.00 & 0.33 & 0.25 & 0.248 & 0.498 & 0.249 & $25 \%$ \\
\hline F12 & $\mathrm{OC}$ & 3.00 & 1.00 & 0.75 & 0.752 & 1.502 & 0.751 & $75 \%$ \\
\hline \multicolumn{2}{|c|}{$\sum$} & 4.20 & 1.46 & & & 2 & 1 & $100 \%$ \\
\hline
\end{tabular}

Note: CIC - Capital investment costs; OC - Operational costs.

Source: Authors' calculation

Table 6 shows the results for the sub-criteria of the qualitative context. Table 6 (part A) shows the comparison matrix of evaluated alternatives in relation to the qualitative context (F2). The results of pairwise comparison show that political and economic environment (F21) is moderately important in comparison to the determinant that refers to legal framework (F22), equally important to sub-criteria related to competition (F23). Further, the sub-criteria related to legal framework (F22) has equal importance compared to the competition (F23).

Table 6: Comparison matrix of sub-criteria relative to qualitative context (A) and vector of eigenvalues of comparison matrix and weight calculation (B)

\begin{tabular}{|c|c|c|c|c|c|c|c|c|c|c|}
\hline \multicolumn{5}{|c|}{$\mathrm{A}$ - comparison matrix } & \multicolumn{6}{|c|}{$\mathrm{B}$ - vector of eigenvalues and weights } \\
\hline \multirow{2}{*}{\multicolumn{2}{|c|}{$\begin{array}{l}\text { F2 Qualitative } \\
\text { context }\end{array}$}} & F21 & F22 & $\mathrm{F} 23$ & F21 & F22 & F23 & \multirow{2}{*}{$\sum$} & \multirow{2}{*}{$\begin{array}{l}\text { Weights } \\
\left(\sum / 3\right)\end{array}$} & \multirow{2}{*}{$\begin{array}{l}\text { Priority } \\
\text { vector }\end{array}$} \\
\hline & & PEE & LF & $\mathrm{C}$ & PEE & LF & $\mathrm{C}$ & & & \\
\hline F21 & PEE & 1 & 2 & 1 & 0.4 & 0.5 & 0.33 & 1.233 & 0.41 & $41 \%$ \\
\hline F22 & LF & 0.5 & 1 & 1 & 0.2 & 0.25 & 0.33 & 0.783 & 0.26 & $26 \%$ \\
\hline F23 & $\mathrm{C}$ & 1 & 1 & 1 & 0.4 & 0.25 & 0.33 & 0.983 & 0.33 & $33 \%$ \\
\hline & 2.5 & 4 & 3 & & & & 3 & 1 & $100 \%$ \\
\hline
\end{tabular}

Note: PEE - Political and economic environment; LF - Legal framework; C - Competition. Source: Authors' calculation

Table 6 (part B) shows the calculation of local weights results, which implies the prioritization of the alternatives at Level 2 regarding the qualitative context. Priority of criteria at Level 2 according to the quantitative context is as follows: F21 - F23 
- F22. Based on the Delphi results, the highest priority related to the qualitative context refers to the political and economic environment $(\mathrm{w}=0.385)$, while the legal framework $(\mathrm{w}=0.26)$ has the lowest priority. Consistency ratio of the pairwise comparison matrix equals $0.029(<0.10)$. Therefore, the weights are shown to be consistent, and the comparison is acceptable.

Table 7 (part A) shows the results of evaluated alternatives relative to the ICTspecific context (F3).The results of the pairwise comparison of the sub-criteria show that human resources availability determinant (F31) is strongly important in comparison to the determinant that refers to infrastructure availability (F32) and strongly important related to sub-criteria related to cultural compatibility (F33). Further, the sub-criteria related to infrastructure availability (F32) has equal importance compared to sub-criteria related to cultural compatibility (F33). Table 7 (part B) shows that priority of criteria at level 2 according to the ICT-specific context is as follows: F31 - F32 - F33. Based on the results, the highest priority related to the ICT-specific context refers to human resources availability $(\mathrm{w}=0.732)$. Infrastructure availability $(\mathrm{w}=0.138)$ and cultural compatibility $(\mathrm{w}=0.129)$ are almost equally important. Consistency ratio of the pairwise comparison matrix is calculated as $0.017(<0.10)$. Thus, the weights are shown to be consistent and the comparison is acceptable.

Table 7: Comparison matrix of sub-criteria relative to ICT-specific context (A) and vector of eigenvalues of comparison matrix and weight calculation (B)

\begin{tabular}{|c|c|c|c|c|c|c|c|c|c|c|}
\hline \multicolumn{5}{|c|}{ A - comparison matrix } & \multicolumn{6}{|c|}{$\mathrm{B}$ - vector of eigenvalues and weights } \\
\hline \multirow{2}{*}{\multicolumn{2}{|c|}{$\begin{array}{c}\text { F3 } \\
\text { ICT-specific } \\
\text { context }\end{array}$}} & F31 & F32 & F33 & F31 & F32 & F33 & \multirow{2}{*}{ ) } & \multirow{2}{*}{$\begin{array}{c}\text { Weights } \\
(\Sigma / 3)\end{array}$} & \multirow{2}{*}{$\begin{array}{l}\text { Priority } \\
\text { vector }\end{array}$} \\
\hline & & HRA & IA & $\mathrm{CC}$ & HRA & IA & $\mathrm{CC}$ & & & \\
\hline F31 & HRA & 1.00 & 5.00 & 6.00 & 0.73 & 0.71 & 0.75 & 2.20 & 0.732 & $73 \%$ \\
\hline F32 & IA & 0.20 & 1.00 & 1.00 & 0.15 & 0.14 & 0.13 & 0.41 & 0.138 & $14 \%$ \\
\hline F33 & $\mathrm{CC}$ & 0.17 & 1.00 & 1.00 & 0.12 & 0.14 & 0.13 & 0.39 & 0.129 & $13 \%$ \\
\hline & & 1.37 & 7.00 & 8.00 & & & & 3 & 1 & $100 \%$ \\
\hline
\end{tabular}

Note: HRA - Human resources availability; IA - Infrastructure availability; CC - Cultural compatibility.

Source: Authors' calculations

\section{(c) Results of final prioritization}

Next step shows the final analysis of evaluated sub-criteria (determinants) for achieving the overall goal set the in AHP model. Table 8 depicts the final ranking expressed in percentage of priority sub-criteria at Level 2 relative to the overall goal, i.e., optimal location selection in the ICT industry. The value for each 
determinant is obtained by multiplying the criterion weight with the alternative's weight according to the observed criterion. To exemplify, $\mathrm{W}_{\mathrm{F} 11}(0.04209)$ is obtained by multiplying the weight of F1 (0.169) from Table 4 and F11 (0.249) from Table 5.

Table 8: Final prioritization of sub-criteria in relation to the overall goal

\begin{tabular}{|c|l|c|c|c|}
\hline \multicolumn{2}{|l|}{ Determinants (sub-criteria) } & Overall priority of sub-criteria & Priority \\
\hline $\mathrm{W}_{\mathrm{F} 11}$ & Capital investment costs & 0.04209 & $4.2 \%$ & 8 \\
\hline $\mathrm{W}_{\mathrm{F} 12}$ & Operational costs & 0.12691 & $12.7 \%$ & 4 \\
\hline $\mathrm{W}_{\mathrm{F} 21}$ & Political and economic environment & 0.18212 & $18.2 \%$ & 2 \\
\hline $\mathrm{W}_{\mathrm{F} 21}$ & Legal framework & 0.11567 & $11.6 \%$ & 5 \\
\hline $\mathrm{W}_{\mathrm{F} 22}$ & Competition & 0.14521 & $14.5 \%$ & 3 \\
\hline $\mathrm{W}_{\mathrm{F} 31}$ & Human resources availability & 0.28402 & $28.4 \%$ & 1 \\
\hline $\mathrm{W}_{\mathrm{F} 32}$ & Infrastructure availability & 0.05354 & $5.35 \%$ & 6 \\
\hline $\mathrm{W}_{\mathrm{F} 33}$ & Cultural compatibility & 0.05005 & $5 \%$ & 7 \\
\hline \multicolumn{2}{|c|}{ Total } & $100 \%$ & \\
\hline
\end{tabular}

Source: Authors' calculations

According to the obtained results presented in this table, the final ranking of determinants is as follows: F31-F21-F23-F12-F21-F32-F33-F11.The priority in selecting an optimal location for a business unit operating in the ICT industry is the human resource availability (F31) with the priority of $28.4 \%$. According to the examined experts' opinion, second priority is reserved for the political and economic environment (F21) with a priority of $18.2 \%$. The third priority refers to the competition (F23) with priority vector of $14.5 \%$. These three together weight $61.1 \%$, making them more important than all other sub-criteria combined. Still, sub-criteria related to operational costs and legal framework account for $12.7 \%$ and $11.6 \%$ respectively. On the other hand, other sub-criteria such as capital investment costs, infrastructure availability, and cultural compatibility have the lowest priority in accomplishing the main goal in the AHP (all lower than 5.5\%). However, these should still be considered when deciding on an optimal location selection in the ICT industry. Generally, the research findings and results of the AHP method are in accordance with the results obtained in the Delphi method. All results and findings can be useful for both academics and practitioners who are interested in selecting optimal location for a business unit operating in the ICT industry. Multicriteria decision-making model has been implemented in selecting a location in the specific service industry, where the location could look as irrelevant at first glance. The research results emphasize human resources and political and economic environment as the most significant. This could be the clear message to the policy makers when defining economic development and ICT priorities, especially in the countries that are seeking progress in this area. 


\section{Conclusions}

The purpose of this paper was to demonstrate and emphasize the importance of location selection for a business unit operating in the ICT industry. In predicting a long-term survival and growth, the location has always played a vital role. Still, to the best of our knowledge, the field of location selection is just starting to be recognized as a key success factor for sustainable growth and development of ICT organizations. Over the recent years, due to a shortage of supply and fierce competition in the ICT sector, the concept has attracted the interest of both academia and practice. Since one of the major steps in selecting an optimal location is the definition of the relevant determinants, the aim of this paper was to define and prioritize the relevant set of determinants for optimal location selection of a business unit operating in the ICT industry. Two hypotheses were set. Both are confirmed. The result of the first phase of the research proves that it is possible to determine the relevant set of factors for location selection of a business unit operating in the ICT industry. This is performed through two steps - the literature review and the two-round Delphi study. The following eight determinants are found important: (a) quantitative context: capital investment costs and operational costs, (b) qualitative context: political and economic environment, legal framework, and competition, and (c) ICT-specific context: human resource availability, infrastructure availability, and cultural compatibility. Results of the second phase of the research confirm that it is possible to prioritize the relevant set of factors for location selection of a business unit operating in the ICT industry. This is validated through an AHP model and analysis. Prioritization is performed by calculation of weights of each determinant for achieving the main goal. The final ranking of determinants shows that three determinants - human resource availability, political and economic environment, and competition account for over $60 \%$ of the final priority vector. Specific nature of ICT and lack of experts is evident through these results, where human resource availability has the highest overall priority weighting $28.4 \%$. According to the results, political and economic environment are ranked second weighting $18.2 \%$. Competition is ranked the third $(14.5 \%)$. This suggests that indeed, political and economic strategies are starting to play an important role in the ICT market, as governments are getting more interested in this industry. In Serbia, the government even named ICT as one of the key priorities of development. The results of this paper contribute to the knowledge relevant to defining economic and development priorities in the ICT sector. Location selection of a business unit operating in the ICT industry plays an important role in enhancing conditions and potentials of local ICT companies, their establishment and development, but also in promoting local ICT businesses to foreign partners. The human resource availability supported by political and economic environment represents the desirable basis for a new business unit in the ICT. This is of great importance for countries with an excellent education in the ICT field, where the government could encourage the business, by providing 
the infrastructure and relevant instruments that could boost the development. Still, this study acknowledges potential limitations despite the relevance of the obtained results regarding the optimal location selection choice in the ICT industry. One is the participation of only one group of stakeholders, i.e., management professional in service ICT companies in Serbia. Professionals from production ICT companies and other stakeholders might have different views, requirements related to the optimal location decision, i.e., shareholders, customers etc. Another limitation of the research is the focus on the small sample of participants from only one country. Consequently, the study results may not be directly applicable to other countries. Finally, the research was focused mainly on outsourcing software companies, while there can be another type of ICT company with specific business models for which these determinants for optimal location selection would not be applicable. Future research on the optimal location selection in the ICT industry should incorporate perspectives from more various stakeholder groups. Moreover, the results should encompass a larger number of experts from more diversified ICT companies based on their business models. These insights may reveal additional useful information regarding the optimal location selection in the ICT industry.

\section{References}

Adler, N.J., Gundersen, A.(2008) International dimensions of organizational behavior. Cengage Learning.

Agrawal, N. M., Khatri, N., Srinivasan, R. (2012) "Managing growth: Human resource management challenges facing the Indian software industry", Journal of World Business, Vol. 47, No. 2, pp. 159-166, doi: 10.1016/j.jwb.2011.04.002.

Andone, I., Pavaloaia, V.D. (2010) "Outsourcing the Business Services", Revista Informatica Economică, Vol.14, No.1/2010, pp. 163-171. Available at: $<$ http://revistaie.ase.ro/content/53/17\%20Andone,\%20Pavaloaia.pdf $>$ [Accessed: Spetember 14, 2017].

Aras, H., Erdoğmuş, Ş., Koç, E. (2004) "Multi-criteria selection for a wind observation station location using analytic hierarchy process", Renewable Energy, Vol. 29, No. 8, pp. 1383-1392, doi: 10.1016/j.renene.2003.12.020.

Boguslauskas, V., Kvedaravičienè, G. (2008) "Strategic outsourcing plan and the structure of outsourcing process", Engineering economics, Vol. 58, No. 3, pp. 60-66. Available at: <http://inzeko.ktu.lt/index.php/EE/article/view/11554> [Accessed: September 14, 2017].

Burdurlu, E., Ejder, E. (2003) "Location choice for furniture industry firms by using Analytic Hierarchy Process (AHP) method", Gazi University Journal of Science, Vol. 16, No. 2, pp. 369-373. Available at $<$ http://dergipark.gov.tr/gujs/ issue/7407/97017> [Accessed: September 20, 2017]. 
Chen, C.F. (2006) "Applying the analytical hierarchy process (AHP) approach to convention site selection", Journal of Travel Research, Vol. 45, No. 2, pp.167174, doi: 10.1177/0047287506291593.

Chen, M. K., Wang, S. C. (2010) "The critical factors of success for information service industry in developing international market: Using analytic hierarchy process (AHP) approach", Expert Systems with Applications, Vol. 37, No. 1, pp. 694-704, doi: 10.1016/j.eswa.2009.06.012.

Chou, T. Y., Hsu, C. L., Chen, M. C. (2008a) “A fuzzy multi-criteria decision model for international tourist hotels location selection", International journal of hospitality management, Vol. 27, No. 2, pp. 293-301, doi: 10.1016/j.ijhm. 2007.07.029.

Chou, S. Y., Chang, Y. H., Shen, C. Y. (2008b) "A fuzzy simple additive weighting system under group decision-making for facility location selection with objective/ subjective attributes", European Journal of Operational Research, Vol. 189, No. 1, pp. 132-145, doi: 10.1016/j.ejor.2007.05.006.

Chu, T.C. (2002) "Facility location selection using fuzzy TOPSIS under group decisions", International journal of uncertainty, fuzziness and knowledge-based systems, Vol. 10, No. 6, pp. 687-701, doi: 10.1142/S0218488502001739.

Comerford, M, Spano, F. (2017). "Labor Costs: The Number-One Site Selection Factor". Available at: $<$ http://www.areadevelopment.com/laborEducation/ feb10/labor-costs-top-site-selection-factor001111.shtml> [Accessed: April 23, 2017]

Dalkey, N., Helmer, O. (1963) "An experimental application of the Delphi method to the use of experts", Management science, Vol.9, No. 3, pp. 458-467, doi: 10.1287/mnsc.9.3.458.

DeVellis, R.F. (2016) Scale development: Theory and applications (Vol. 26). Sage publications.

Drezner, Z., \& Hamacher, H. W. (2001) Facility location: applications and theory. Springer Science \& Business Media.

Duvivier, C., Polèse, M., Apparicio, P. (2018) "The location of information technology-led new economy jobs in cities: office parks or cool neighbourhoods?", Regional Studies, Vol. 52, No. 6, pp. 756-767, doi: 10.1080/00343404.2017.1322686.

Eskandari, H. et al. (2007) "Enhancing the undergraduate industrial engineering curriculum: Defining desired characteristics and emerging topics", Education + Training, Vol. 49, No. 1, pp. 45-55, doi: 10.1108/00400910710729875.

European Commission (2017) "European Union Statistics. Retrieved from ICT specialists in employment". Available at: $<$ http://ec.europa.eu/eurostat/statisticsexplained/index.php/ICT_specialists_in_employment $>$ [Accessed: September 28, 2017]. 
Govindan, K. et al. (2016) "Effect of product recovery and sustainability enhancing indicators on the location selection of manufacturing facility", Ecological indicators, Vol. 67, pp. 517-532, doi: 10.1016/j.ecolind.2016.01.035.

Gušavac, B.A., Stojanović, D., Kuzmanović, M. (2014) “Conjoint-Based Approach to Location Choice in the Retail Industry: Conceptual Framework". In: Levi Jakšić M., Rakočević S.B., Martić M., eds, Innovative Management and Firm Performance, London: Palgrave Macmillan, doi: 10.1057/9781137402226_20.

Indiatsy, C.M. et al. (2014) "The application of Porter's five forces model on organization performance: A case of cooperative bank of Kenya Ltd", European Journal of Business and Management, Vol. 6, No. 16, pp.75-85. Available at: $<$ http://erepository.uonbi.ac.ke/bitstream/handle/11295/73376/FULL\%20 TEXT\%20.pdf\%20?sequence=1\&isAllowed=y $>$ [Accessed: September 23, 2017].

Kadokawa, K. (2011) "Infrastructure support and new plant formation: A factor analysis approach", Journal of Geography and Regional Planning, Vol. 4, No. 4, pp. 231-242. Available at: $<$ https://academicjournals.org/journal/JGRP/ article-abstract/CDAC0B540812> [Accessed: October 1, 2017].

Kahraman, C., Ruan, D., Doğan, I. (2003) "Fuzzy group decision-making for facility location selection", Information Sciences, No. 157, pp. 135-153, doi: 10.1016/S0020-0255(03)00183-X.

Kowalkowski, C., Kindström, D., Brehmer, P. O. (2011) "Managing industrial service offerings in global business markets", Journal of Business \& Industrial Marketing, Vol. 26, No. 3, pp. 181-192, doi: 10.1108/08858621111115903.

Lee, J. N. (2006) "Outsourcing alignment with business strategy and firm performance", Communications of the Association for Information Systems, Vol. 17, No. 1, pp. 1124-1146. Available at: <https://aisel.aisnet.org/cais/vol17/ iss1/49/> [Accessed: September 14, 2017].

Linstone, H. A., Turoff, M. (2002) The Delphi Method: Techniques and Applications, London: Addison-Wesley.

Madura, J., Fox, R. (2011) International Financial Management. Cengage Learning.

Matteucci, N. et al. (2005) "Productivity, workplace performance and ICT: Industry and firm-level evidence for Europe and the US", Scottish Journal of Political Economy, Vol. 52, No. 3, pp. 359-386. doi: 10.1111/j.0036-9292.2005.00349.x.

Mousavi, S. M. et al. (2013) "Multi-Criteria Decision Making for Plant Location Selection: An Integrated Delphi-AHP-PROMETHEE Methodology", Arabian Journal for Science and Engineering, Vol. 38, No. 5, pp. 1255-1268, doi: 10.1007/s13369-012-0361-8.

Muñiz, A. S., Cuervo, M. V. (2014) "ICT technologies in Europe: A study of technological diffusion and economic growth under network theory", Telecommunications Policy, Vol. 38, No. 4, pp. 360-370, doi: 10.1016/j.telpol. 2013.12.003. 
Narula, R., Santangelo, G. D. (2009) "Location, collocation and R\&D alliances in the European ICT industry", Research Policy, Vol. 38, No. 2, pp. 393-403, doi: 10.1016/j.respol.2008.11.005.

Novakowski, N., Wellar, B. (2008) "Using the Delphi technique in normative planning research: methodological design considerations", Environment and Planning A, Vol. 40, No. 6, pp. 1485-1500, doi: 10.1068/a39267.

Okoli, C., Pawlowski, S. D. (2004) "The Delphi method as a research tool: an example design considerations and applications", Information \& Management, Vol. 42, No. 1, pp. 15-29, doi: 10.1016/j.im.2003.11.002.

Özcan, T., Çelebi, N., Esnaf, Ş. (2011) "Comparative analysis of multi-criteria decision making methodologies and implementation of a warehouse location selection problem" Expert Systems with Applications, Vol. 38, No. 8, pp. 97739779, doi: 10.1016/j.eswa.2011.02.022.

Pedrelli, M. (2001) Developing countries and the ICT revolution, Luxembourg: Directorate General for Research. Available at: <http://www.europarl.europa. eu/RegData/etudes/etudes/join/2001/296692/DG-4-JOIN_ET(2001)296692_ EN.pdf $>$ [Accessed: August 25, 2017].

Pen, C. J. (1999) Improving the behavioral location theory. Groningen: Faculty of Spatial Sciences.

Porter, M. E. (1980) Competitive Strategy: Techniques for Analyzing Industries and Competitors, New York: The Free Press.

Porter, M. E. (1985) Competitive Advantage: Creating and Sustaining Superior Performance, New York: The Free Press.

Porter, M. E. (2008), "The five competitive forces that shape strategy", Harvard Business Review, Vol. 86, No. 1, pp. 78-93. Available at: <https://hbr. org/2008/01/the-five-competitive-forces-that-shape-strategy> [Accessed: November 21, 2018].

Redding, S. J., Turner, M. A. (2015) "Transportation costs and the spatial organization of economic activity", Handbook of regional and urban economics, Vol. 5, pp. 1339-1398, doi: 10.1016/B978-0-444-59531-7.00020-X.

Saaty, T. L. (1977) "A scaling method for priorities in hierarchical structures", Journal of Mathematical Psychology, Vol. 15, No. 3, pp. 234-281, doi: 10.1016/0022-2496(77)90033-5.

Saaty, T. L. (1980) The Analytic Hierarchy Process: Planning, Priority Setting, Resource Allocation (Decision Making Series). McGraw-Hill.

Saaty, T. L. (1986) "Axiomatic Foundation of the Analytic Hierarchy Process", Management Science, Vol. 32, No. 7, pp. 841-855, doi: 10.1287/mnsc.32.7.841.

Saaty, T. L. (1990) "How to make a decision: The analytic hierarchy process", European Journal of Operational Research, Vol. 48, No. 1, pp. 9-26, doi: 10.1016/0377-2217(90)90057-I. 
Saaty, T. L. (2008) "Decision making with the analytic hierarchy process", International journal of services sciences, Vol. 1, No. 1, pp. 83-98, doi: 10.1504/IJSSci. 2008.01759.

Saaty, T. L. (2013) "Analytic Hierarchy Process". In: Gass, S.I., Fu, M.C., eds, Encyclopedia of Operations Research and Management Science, Boston: Springer.

Stojanović, D. (2005) "Differences in location choice in building production and services objects". In Proceedings of the IX international conference of project management, Zlatibor: Faculty of organizational sciences, pp. 304-309.

Tornjanski, V. et al. (2015) "The prioritization of open innovation determinants in banking", Industrija, Vol. 43, No. 3, pp. 81-105.

Tzeng, G. H. et al. (2002) "Multicriteria selection for a restaurant location in Taipei", International journal of hospitality management, Vol. 21, No. 2, pp. 171-187, doi: 10.1016/S0278-4319(02)00005-1.

Van Noort, E. A., Rejimer, J. I. (1999) "Location choice of SMEs. The most important determinants", Zoetermeer: EIM Small Business Research and Consultancy.

Van Oort, F., Weterings, A., Verlinde, H. (2003) "Residential amenities of knowledge workers and the location of ICT-Firms in the Netherlands", Tijdschrift voor economische en sociale geografie, Vol. 94, No. 4, pp. 516-523, doi: 10.1111/14679663.00278 .

Yang, J., Lee, H. (1997) "An AHP decision model for facility location selection" Facilities, Vol. 15, No. 9/10, pp. 241-254, doi: 10.1108/02632779710178785.

Yong, D. (2006) "Plant location selection based on fuzzy TOPSIS", The International Journal of Advanced Manufacturing Technology, Vol. 28, No. 7-8, pp. 839-844, doi: 10.1007/s00170-004-2436-5. 


\title{
Odabir lokacije za novu poslovnu jedinicu u ICT industriji
}

\author{
Sanja Marinković ${ }^{1}$ Ilija Nikolić ${ }^{2}$, Jovana Rakićevic ${ }^{3}$
}

\begin{abstract}
Sažetak
Teorija lokacije proučava utjecaj lokacije na bilo koju ekonomsku aktivnost, pokušavajući razumjeti gdje se poslovne operacije trebaju smjestiti i koji je razlog takve odluke. Cilj ovog rada je raspraviti i odrediti prioritete ključnih odrednica lokacije za uspješan odabir optimalne lokacije za poslovnu jedinicu u ICT industriji. U radu se ističe važnost ovog koncepta u ICT sektoru danas, u vrijeme digitalizacije $i$ velike internetske revolucije. Inicijalne odrednice formirane su na temelju pregleda literature i procjenjuju se kroz dva kruga Delphi studije među stručnjacima ICT tvrtki u Srbiji. Drugi cilj istraživanja bio je postići konsenzus oko relativne važnosti dogovorenih odrednica. Prema dobivenim rezultatima korištenjem AHP modela odlučivanja, prioritet pri odabiru lokacije za poslovnu jedinicu u ICT industriji je dostupnost ljudskih resursa, drugi je političko i gospodarsko okruženje, a treće je natjecanje. Rezultati istraživanja potvrđuju da političke i ekonomske strategije igraju važnu ulogu u ICT tržištu, jer vlade pokazuju sve veći interes za ovu industriju. Istraživanjem je dokazano da je zbog nedostatka ponude rada i žestoke konkurencije u ICT sektoru, koncept odabira lokacije važan čimbenik uspjeha za održivi rast i razvoj ICT organizacija.
\end{abstract}

Ključne riječi: odabir lokacije, odrednice lokacije, Delphi studija, AHP model odlučivanja, ICT industrija

JEL klasifikacija: D70, L21, M15, M21, R39

1 Izvanredni profesor, Sveučilište u Beogradu, Fakultet organizacijskih znanosti, Jove Ilica 154, 11000 Beograd, Srbija. Znanstveni interes: upravljanje tehnologijom, upravljanje inovacijama, menadžment poslovanja.Tel.: +381698893176.E-mail: marinkovic.sanja@fon.bg.ac.rs.

2 Poslijediplomand, Sveučilište u Beogradu, Fakultet organizacijskih znanosti, Jove Ilica 154, 11000 Beograd, Srbija. Znanstveni interes: ICT menadžment, međunarodno poslovanje. E-mail: ilija89.n@gmail.com.

${ }^{3}$ Asistent, Sveučilište u Beogradu, Fakultet organizacijskih znanosti, Jove Ilica 154, 11000 Beograd, Srbija Znanstveni interes: upravljanje tehnologijom, tehnološko poduzetništvo. Tel.: +381698893562.E-mail: jovana.rakicevic@fon.bg.ac.rs. 